\title{
Desrazão \& ludicidade em Nelson Rodrigues, Campos de Carvalho e Guimarães Rosa
}

\author{
Unreason \& play-element in Nelson Rodrigues, Campos de Carvalho e Guimarães Rosa
}

\author{
Norma Côrtes \\ Doutora em Ciência Política \\ Professora do Instituto de História \\ da Universidade Federal do Rio de Janeiro \\ ncortes.ufrj@gmail.com
}

Resumo: Em A Falecida, Nelson Rodrigues construiu um universo imagético de delírio e brincadeiras que pavimentou a aceitação social de uma nova sensibilidade estética marcada por desrazão \& ludicidade. A mesma sensibilidade apareceu nas últimas obras de Campos de Carvalho e em Guimarães Rosa. Com fortes acentos lúdico-humorísticos, tais obras são fragmentadas, esgarçam os limites da linguagem e, tal como na poesia, exploram apelos sonoros numa cadência (dis)rítmica/cacofônica apresentando o mundo (ficcional) em estado de pura desordem. Não obstante suas diferentes temáticas, tais semelhanças formais expressam os esforços poéticos de rompimento com padrões racionalistas da verossimilhança realista - o que envolve o estabelecimento de novo acordo societal acerca do estatuto da arte e revela os termos constituintes do "regime de prazeres" vigente na sociedade brasileira dos anos 1960 . Palavras-chave: Cultura e sociedade; Brasil, anos 1960; dramaturgia, literatura, jogo e humor.

\begin{abstract}
Nelson Rodrigues built a imagistic delirium universe that paved the social acceptance of a new aesthetic sensibility marked by unreason \& play-elements. The same sensitivity appeared in the last works of Campos de Carvalho and Guimarães Rosa. With strong ludic and humorous accents, such works are fragmented, fray the boundaries of language and, as in poetry, explore sound appeals in cadence (dis) rhythmic / cacophonous presenting the world (fictional) in a state of pure disorder. Despite their different themes, such formal similarities express the poetic efforts to break with rationalist standards of realistic verisimilitude, which involves the establishment of new societal agreement on the art status and reveals the constituent terms of the current "pleasures regime" in Brazilian society of 1960.
\end{abstract}

Keywords: Culture and society; Brazil, 1960; drama, literature, play and humor. 
Nelson Rodrigues (1912 - 1980) não manifestou grande entusiasmo pela versão cinematográfica de A Falecida. Com direção e roteiro de Leon Hirszman ${ }^{1}$, o filme foi lançado em 1965 e reunindo um grande elenco, encabeçado por Fernanda Montenegro, recebeu boa crítica além da premiação especial no I Festival Internacional de Cinema do Rio de Janeiro tendo também sido exibido como hors concours no Festival de Veneza daquele mesmo ano. Não obstante tudo isso, o dramaturgo não se encantou com as opções estéticas de Hirszman e, incidentalmente, falando a propósito de sua própria obra teatral, emitiu um juízo bastante severo sobre a adaptação fílmica de sua peça:

Se eu não escrevesse [disse Nelson Rodrigues], seria um desgraçado. A rigor, se examinar bem, todos os meus personagens são tristes. Salvo algum esquecimento, não vejo ninguém alegre. Humor? Faço. O fracasso de Leon Hirszman com A Falecida, no cinema, foi exatamente a falta de humor. (VOGT e WALDMAN, 1985: 62).

Não era a primeira vez que o dramaturgo se sentia mal compreendido. Em verdade, durante longo tempo, houve uma nódoa de desinteligência quanto às suas ambições teatrais. Porque a recepção de suas peças, tanto a do público quanto a da crítica, não foi exatamente triunfal. Depois de o Vestido de noiva, que logrou grande êxito de crítica, mas que havia sido encenado dez anos antes da primeira montagem de A Falecida (ou seja, havia sido encenado em 1943), Nelson Rodrigues não provou mais dos bons frutos do reconhecimento ou da consagração. E embora houvesse concordância acerca do pioneirismo cênico contido nas suas peças — o que, às vezes, era maldosamente atribuído às revolucionárias montagens de Ziembinski —, ele se instalou (e/ou foi posto...) no lugar do artista maldito que raivosamente deblaterava contra a obtusidade da plateia.

Todo esse desacordo não se devia apenas à obscenidade das peças (apesar de as criaturas rodriguianas parecerem estar sempre possuídas por uma volúpia malsã — o que, certamente, aviltava o moralismo da "boa sociedade"). Mas o problema não pode ser

\footnotetext{
${ }^{1}$ A Falecida (1965). Direção: Leon HIRSZMAN | Roteiro: L. Hirszman e Eduardo Coutinho | Fotografia: José Medeiros | Música: Radamés Gnatalli, sobre tema de Nelson Cavaquinho | Montagem: Nello Melli | Produção: Joffre Rodrigues e Aluizio Leite Garcia | Elenco: Fernanda Montenegro, Ivan Cândido, Nelson Xavier, Paulo Gracindo, Joel Barcelos, Dinorah Brillanti, Hugo Carvana, Zé Keti, Glória Ladany, Virgínia Vale, Wilmar Menezes, Oswaldo Ferreira, Wanda Lacerda. |(P\&B) | Duração: 85 min. | Recebeu Prêmio Especial do Júri no I Festival Internacional do Filme do Rio de Janeiro em 1965; e foi participante hors concours do Festival de Veneza do mesmo ano. Disponível em:<http://www.nelsonrodrigues.com.br/site/>. Acesso: 03 jul. 2014.
} 
atribuído tão-somente ao fato de o seu teatro ter sido considerado como pura pornografia. Porque aliado à exibição cênica desse mundo depravado, havia um elemento de natureza estética que foi, realmente, obstáculo para o entendimento das suas intenções poéticas. E o problema tanto residia na ausência de clareza acerca do estatuto representacional da sua obra quanto também na imprecisão sobre o gênero teatral das peças — É farsa? É tragédia? É melodrama? É comédia? É non sense ou teatro do absurdo? Enfim: afora a acusação de pornografia; para a plateia, o desconforto residia na incompreensão quanto aos graus de realismo (ou não) das peças e sobre os gêneros dramatúrgicos envolvidos nas encenações. Que dizer, ao fim dos espetáculos, além do espanto em virtude das peripécias dramáticas, sobrava o incomodo das seguintes inquietações: Isto é sério?! Foi feito para rir ou para comover? É farsa ou melodrama?

Eis a razão de o dramaturgo ter desgostado da adaptação feita por Leon Hirszman. Afinal, o cineasta também não compreendeu que em A Falecida havia humor, zombaria e muita farsa. E, com efeito, acabou imprimindo ao seu filme um tom excessivamente austero e "cinemanovista"2. Quer dizer, salvo honrosas e importantes exceções, as primeiras vogas da recepção da obra de Nelson Rodrigues foram marcadas por um desacordo quanto às intenções do autor. E isso porque suas peças habitam uma "zona cinza”, incerta, preenchida por ambiguidades que não só desconheciam os limites canônicos dos gêneros dramáticos como também, e pior ainda, romperam com o naturalismo da verossimilhança realista embaralhando as fronteiras entre realidade e fantasia.

Até mesmo Sábato Magaldi — que foi amigo de Nelson e é um dos mais importantes crítico e estudioso de sua obra - até mesmo ele, repito, insinuou uma exegese que, a meu ver, é excessivamente vincada pela realidade social, pois aproximava o ambiente contido nas crônicas de $A$ vida como ela é... da criação poética do teatro

\footnotetext{
2 "O roteiro de Eduardo Coutinho e Leon Hirszman confirma a tomada de distância do universo rodriguiano. O tom explosivo é violentamente rebaixado, o tempo é distendido, os personagens como que se calam para que as imagens falem. Belas e austeras imagens, convém notar, que parecem aspirar à conciliação entre uma mise-en-scène jansenista, acrescida de um toque de nouvelle vague, e um clima de subúrbio carioca criado com muita eficácia. A música dos letreiros não deixa dúvida quanto à natureza deste filme, que utiliza um quadro popular (não foge a ele), mas procura, plano após plano, tomar distância do que existe de irremediavelmente popular no texto original. Em definitivo, A falecida é um filme sobre o povo, mas não para o povo; sobre o subúrbio, mas não para o subúrbio. Leon Hirszman observa, como um aplicado voyeur, esse mundo de que Nelson Rodrigues partilha intensamente. Tudo parece concebido para reforçar a distância em relação a Nelson e afirmar o caráter intelectual, cinema-novista, distingué, em suma, do filme: a luz de José Medeiros, por exemplo, e sobretudo a interpretação terrivelmente sóbria, contida e em todos os sentidos admirável de Fernanda Montenegro. É como se Leon julgasse o mundo de Nelson bruto demais e buscasse adaptá-lo" (ARAÚJO, s/d: s/p).
} 
rodriguiano. Refiro-me à ocasião em que o crítico organizou a edição do Teatro Completo e optou por agrupar as chamadas "tragédias cariocas" (que se inauguraram justamente com A Falecida), distinguindo-as tanto das "peças psicológicas" quanto das "peças míticas". A questão é que, apesar de ser profícua, essa classificação dramatúrgica também estabeleceu elos causais excessivamente estreitos e diretos entre a temática das crônicas do jornal, que se compraziam em descrever as dores \& delicias do prosaísmo suburbano, e os ânimos motivacionais das chamadas "tragédias cariocas". Como se Nelson Rodrigues tivesse simplesmente transferido os fatos narrados em suas crônicas para o palco. Em Sábato Magaldi tal argumento apareceu assim:

O compromisso com o mundo exterior, o cotidiano, a existência próxima ao palpável, Nelson vivia na sua faina diária de jornal. Em 1951, ele começou, na Ultima Hora do Rio, a publicação de A vida como ela é.., uma quase inacreditável coletânea de histórias, em que tratava de preferência da vida suburbana carioca. Esses folhetins, independentes entre si, valeram a Nelson uma extraordinária popularidade, aumentando além de qualquer cifra otimista a tiragem do jornal. A dramaturgia, depois da acolhida de Vestido de Noiva, trancou-se em paredes 'desagradáveis'. Era natural que o novo diálogo com o leitor, espontâneo e direto, tivesse repercussão no teatro a ser escrito. O exercício de A vida como ela é... representava um preparo espontâneo para as tragédias cariocas. Elas viriam como fatalidade na evolução do autor.

[...] acredito que as tragédias cariocas sintetizem as características de Nelson Rodrigues. Quando ele lidou mais com o subconsciente e as fantasias inconscientes [nas peças míticas e psicológicas - NC] se entregava a um delírio que podia prescindir da censura da realidade. $\mathrm{O}$ voo poético parecia especialmente livre, por recusar quaisquer limites. Mas o público tinha dificuldade de identificar-se com um homem entregue à imaginação e ao desvario, sem os prosaicos e exigentes mandamentos do cotidiano.

Ao situar as personagens, nas tragédias cariocas, sobretudo no cenário da Zona Norte do Rio, Nelson deu-lhes uma dimensão palpável no real, mas não abdicou da carga subjetiva anterior. [...] As tragédias cariocas, portanto, unindo a realidade a os impulsos interiores, promovem a síntese do complexo homem rodriguiano (MAGALDI, 2004: 94).

Seja como for, convém salientar que essa alegada inclinação para a realidade da vida suburbana não redimiu o teatro de Nelson Rodrigues. Muito ao contrário. Porque 
quando A Falecida foi primeiramente encenada (em 08 de junho de 1953, no Theatro Municipal do Rio de Janeiro, numa montagem da recém-criada Companhia Dramática Nacional), ela foi apreciada sob forte suspeição. E os críticos, exatamente porque repudiavam a representação daquela realidade tosca, fizeram pesada objeção contra o estilo dramatúrgico de Nelson Rodrigues. E foi sob esse ânimo que José Maria Monteiro, crítico teatral de $O$ Jornal, escreveu:

A Falecida "[...] parece um prato muito enfeitado, tendo no fundo um bife duro e sem paladar. É a história, em que não há uma estrutura dramática, nem preparo cênico, nem caracterização dos personagens. Um 'fait-divers' dialogado em gíria, que não emociona nem interessa; o quotidiano mais rasteiro, que o autor não teve forças para elevar ao plano artístico e muito menos dramático, um folhetim que se transviou no palco [...] a procura mórbida do mórbido (Apud, ENCICLOPÉDIA ITAÚ CULTURAL, s/d).

Apresentada como "farsa trágica em três atos", A Falecida conta a história de um casal suburbano, Toninho e Zulmira - ele, desempregado, mas jogador e amante das apostas; ela, tuberculosa e obcecada pelos delírios de ostentação e luxo das exéquias de seu próprio funeral. A cena inicial da peça antecipa toda sua estrutura dramática, que começa numa consulta da protagonista a uma cartomante evidentemente charlatã, abrindo-se, a partir daí, para uma série de eventos ordinários reveladores de um mundo humanamente miserável, funéreo, insano e preenchido pelos caprichos da desrazão (i.é por uma ordem causal ilógica, et pour cause, injusta) e também pelos excessos do vício e da loucura.

Antes que essa descrição sumária dê a entender que aí se encerra um ambiente soturno, convém lembrar que a peça consiste numa farsa (farsa trágica, mas é farsa...) e traz para o palco a comicidade típica das trapaças. Porque os planos mirabolantes e ardilosos dos protagonistas nunca resultam em êxito: Zulmira, a falecida, não passa de uma grande trapalhona, que acaba por conseguir um enterro miserável. Enquanto seu marido enriquece, mas por causa de uma chantagem humilhante em que, amarga e tardiamente, percebe que fora enganado o tempo todo. Em suma, ao contrário da plateia que compreende nitidamente todos os indícios da sandice, nem Zulmira nem Toninho enxergam o mundo com acuidade. Néscios, eles vivem imersos em suas elucubrações fúnebres ou em delírios de apostas triunfais, enquanto todos os seus passos rumam para 
um destino anunciadamente trágico cuja desinteligência e errância são constrangedoramente cômicas.

É claro que essa forma de comicidade não conduz o expectador à franca gargalhada ou à leveza da diversão (agora, em obediência a sua etimologia ${ }^{3}$, entendida somente como evasão ou experiência de escapismo - HOUAISS, 2002, s/p). Longe disso. Porque ao invés de ser parceiro da alegria, no teatro rodriguiano, o riso é amargo e vem acompanhado de melancolia e desilusão ${ }^{4}$. A audiência da peça resulta, portanto, numa experiência esteticamente desconcertante e existencialmente amarga. Afinal, não apenas foram desafiadas as certezas acerca dos graus de percepção que deveriam assinalar a distância entre a realidade e a ilusão; como também ruíram as fronteiras que separariam os gêneros dramáticos; e, num misto de seriedade e des/graça, restou apenas a desconfortável constatação (de cariz metafísico) da ausência de razoabilidade das coisas do mundo ou de sentido para a vida humana.

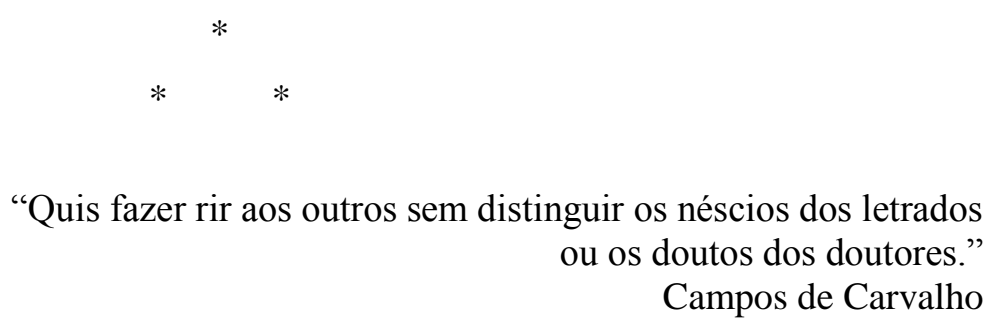

Em 1964, depois de quase uma década da primeira encenação de A Falecida, Walter Campos de Carvalho (1916 - 1998) publicou seu último romance ${ }^{5}$, O púcaro búlgaro. Antes, ele já publicara alguns outros livros, que haviam obtido boa recepção tanto de público quanto de crítica e possuíam uma comicidade galhofeira razoavelmente semelhante $^{6}$. Mas foi em $O$ púcaro búlgaro que o humor desse autor encontrou a excelência literária. E, a esse propósito Antonio Olinto asseverou:

\footnotetext{
${ }^{3}$ Etimologia da palavra diversão (do latim diversìo,ónis) - "digressão, diversão", do verbo divertère 'afastarse, apartar-se, ser diferente, divergir.

${ }^{4}$ Faço remissão a dois livros importantes para melhor entendimento desse ponto: ROUANET (2007) - e nesse caso, evoco a figura de Machado de Assis -; MARQUES (2012).

${ }^{5}$ Entre 1968 e 1978, ele também colaborou para o Pasquim e o Estado de São Paulo, mas desde 1964 (depois de $O$ púcaro búlgaro) ausentou-se da cena literária e encerrou as suas atividades como romancista. Há vários estudos sobre vida e obra de Campos de Carvalho, dentre outros, cf. particularmente (BATELLA, 2004).

${ }^{6}$ Segundo o prefaciador da Obra Reunida, a literatura de Campos de Carvalho está atravessada pela [...] "utilização consistente de dois recursos: o humor consequente, de extração filosófica, avesso e parceiro inseparável da visão trágica da existência, presença marcante em $A$ lua vem da Ásia e senhor absoluto de $O$ púcaro búlgaro, e a imaginação delirante, que não se detém perante o insólito. Por essa via, o autor se aproximará do surrealismo, [...]. Quanto mais delirante, mais fundo a imaginação toca o cerne da realidade. $\mathrm{Na}$ verdade, o autor está mais para realista do que para surrealista, embora isso ofenda aos espíritos bem
} 
[...] Desde A lua vem da Ásia que se viu existir, em Campos de Carvalho, um escritor realmente novo, um homem que não se deixava prender em classificações ou correntes. Chuva imóvel e Vaca de nariz sutil foram ambos, um avanço em sua literatura, mas percebi, no último principalmente, que o autor se repetia e entrava num tipo diferente de mesmice, que eu chamaria de 'a mesmice da originalidade'. Agora, porém, com $O$ púcaro búlgaro, penetra Campos de Carvalho em terreno diferente, e sem evidencias de forçada originalidade. [...] O tom geral de $O$ púcaro búlgaro é o cômico. Sua comicidade não fica, porém, apenas em situação externas. Jogo de palavras, fá-lo ele a cada instante, e sua modificação estilística se adestra com isso. A partir dos dois proparoxítonos, púcaro e búlgaro, vai Campos de Carvalho tecendo sua risibilidade vocabular, acumulando quiproquós como os bons humoristas de qualquer tempo e arte, Rabelais ou Chaplin, Marivaux ou Tashlin. Do verbalismo, sobe Campos de Carvalho à comicidade de personagens, à de conteúdos e mesmo a uma espécie de comicidade verbal do começo, o que fecha o livro num círculo e torna a expedição para a descoberta da Bulgária um correr atrás de tudo e de nada, um exercício que já é fim, e uma busca de realização de vida que acaba sendo violenta e dura realização de arte (OLINTO, 1966:33).

A história de $O$ púcaro búlgaro é engraçadíssima. Trata-se de um romance acerca das enlouquecidas peripécias de seis personagens que tentam organizar uma viagem de expedição científica para comprovar, objetiva e empiricamente, a existência do púcaro búlgaro. Além de zombar da seriedade das descobertas científicas e de infundir poderoso escárnio nas indagações filosóficas sobre o ser — afinal, o púcaro búlgaro não é nada; é coisa realmente inexistente (seja lá o estatuto ôntico que essa afirmação envolva!) —, a obra consiste numa sucessão disparatada e cronologicamente anárquica (a numeração dos capítulos e a ordem temporal são caóticas e aleatórias) de périplos extravagantes, cuja saga se conclui numa hilariante e surpreendente partida.

\section{A PARTIDA}

PERNACCHIO — Quantas?

RADAMÉS - Me dê duas. Bem baixas, porém altas.

pensantes, amantes da boa lógica. O objetivo primordial dessa obra singular talvez seja justamente livrarnos da sedução da boa lógica" (MOISÉS, 2002: 16). 
EU — Me dê uma. E mesa.

PERNACCHIO - Espera a vez, porra! Eu quero três. O RELÓGIO - Tic-tac, tic-tac, tic-tac, tic-tac...

EU - Mesa, já dei.

PERNACCHIO - (Assobiando a protofonia do Guarani)...

RADAMÉS - Por falar em já dei, como irá indo a Rosa? Aquilo é que eram panquecas!

PERNACCHIO — Também mesa.

RADAMÉS - Aposto duzentos. Pensando bem, até que Rosa não era lá essas coisas. Senti mais ter perdido a cabra.

EU — Vamos mudar de assunto?... Não vejo.

$[\ldots] /[\ldots]$

O RELÓGIO (passando das 11h50min para as duas) — Tic-tac,tic-tac, tictac...

RADAMÉS - Eu sempre desejei conhecer a Bulgária.

PERNACCHIO, EU — Mas o Sr. não é búlgaro?!

RADAMÉS - Saí de lá muito criança, meses apenas. Me dê três. O tal cearense conseguiu convencer meu pai de que o Ceará existia mesmo, e meu pai organizou a primeira expedição búlgara para descobrir o Ceará.

EU - Me dê uma. E descobriu?

RADAMÉS - Se descobriu, não sei. O fato incontestável é que moramos em Quixeramobim e em Quixadá durante quarenta anos. O que não deixa de ser uma prova de peso.

PERNACCHIO - Vou pedir uma. Então quer dizer que o Ceará também existe?

RADAMÉS - Sou eu quem fala? - Que diabo, se nem o Ceará nem a Bulgária existem, então eu fico mesmo num mato sem cachorro. Bato mesa. Mas como dizem que quem não tem cão caça com gato, eu pelo menos tenho o meu gato para caçar um jeito de sair dessa enrascada.

EU - Mesa, também. O diabo é que o seu gato não é de nada, professor. E ele, pelo menos — nasceu em algum lugar?

RADAMÉS - Presumo que no cu da gata, para não dizer pior. Quanto a não ser de nada, só por causa do seu ar ausente, digo que Deus é o rei dos ausentes e nem por isso você é capaz de dizer que ele não exista.

EU - Existe tanto quanto o Ceará ou a sua Bulgária.

PERNACCHIO - O que não quer dizer absolutamente nada. Bato.

(CARVALHO, 2002: 380 - 382. Os grifos são meus). 
E assim termina o último capítulo de $O$ púcaro búlgaro. Nele, Campos de Carvalho levou ao extremo as brincadeiras com os jogos da linguagem. E manejando com as ambiguidades da homonímia, a partir das engrenagens da palavra, exibe os artifícios de montagem e desmontagem das expressões da fala e dos lugares comuns. Com efeito, tanto expõe os limites do princípio da identidade (os entes do mundo não são unívocos) quanto rompe com o estatuto referencial da linguagem (pois não há correspondência entre as palavras e as coisas), convertendo o término da epopeia expedicionária num prosaico jogo de carteado. Sem qualquer intervalo, numa queda vertiginosa que foi do épico à trivialidade mais ordinária e chula, e com um único trocadilho, o autor transformou a sublimidade das inquietações filosóficas (O problema da existência de Deus) no mais desabrido escracho (Nada existe; e daí? Bato... fim de jogo).

Toda a aventura, todas as personagens, toda a linguagem, tudo em $O$ púcaro búlgaro conduz o leitor a ingressar nesse universo lúdico, ilógico e "antes do sério". Esse é o território onde reinam absolutos a brincadeira, infância, o riso, o ócio e o jogo ${ }^{7}$. Tratase de um mundo imaginário, presidido pela errância do acaso (rechaçando o determinismo da lógica causal) cujo idioma desconhece razoabilidade e em grande algaravia permanece num estado de perene trocadilho, sendo quase tatibitate. Nesse mundo primevo, o encaixe entre as palavras e as coisas permanece sem ter sido concluído, pois o pacto nominativo acerca de todos os seres e haveres do mundo - o verde e o azul, a casa e a rua, o certo o errado, o meu e o teu etc., etc... - esse "contrato ontológico" ainda não se encerrou e, pior ainda, treme vibrando sob o risco de jamais vir a se completar.

A experiência de leitura de Campos de Carvalho, portanto, sequestra as nossas habilidades interpretativas ordinárias porque suas palavras se erguem como cifras ambíguas, absoltamente hilariantes, que exatamente em virtude disso, provocam perplexidade, desconcerto e espanto. Contrariando o caráter especular da linguagem ${ }^{8}$, ele nos leva de volta a um lugar original, remoto e já esquecido, mas ainda habitado por um radical (e, de certa forma, infantil) estranhamento do estar / ser no mundo. Eis o umbral da inquietação ontológica — problema que, de resto, tem assaltado a consciência

\footnotetext{
${ }^{7}$ Vale lembrar que o território do jogo também aparece nos caracteres das personagens de A Falecida, que igualmente termina num jogo de futebol com os gritos enlouquecidos de Toninho que, na boca de cena, esbraveja a sua aposta de duzentos contos contra a multidão /a plateia.

${ }^{8}$ Situação em que a linguagem é locução: veículo que enuncia, descreve e representa os haveres e seres contidos na realidade.
} 
ocidental e nos levado aos confins da gratuidade da existência (e da arte, particularmente) e cuja melhor formulação foi dada pela tragédia shakespeariana: ser ou não ser, eis a questão...

A literatura de Campos de Carvalho abandonou a pretensão realista, descritiva, transportando os seus leitores para o momento criadeiro original, quando, na incubadora do mundo, tudo ainda poderia vir a ser. Com efeito, seu romance nos devolve ao encantamento inicial (a graça infantil e maravilhada) e encerra toda a realidade, pois nela está contida a pletora caótica dos entes que são, mas, principalmente e também, o nada, os púcaros búlgaros, "Nonada" ${ }^{9}$... aqueles que decididamente não-são.

Quando Campos de Carvalho lançou o seu último romance, João Guimarães Rosa (1908 - 1967) já havia publicado Grande sertão: veredas (1956), que, desde a primeira hora, fora imediatamente considerado como um monumento da literatura brasileira. Feita as devidas reservas, pode-se afirmar que $O$ púcaro búlgaro traduziu para a clave cômica as mesmas inquietações metafísicas que se encontravam na obra prima de Rosa. E não obstante a derrisão iconoclasta de Campos de Carvalho tenha expulsado o Criador do mundo dos homens (e nesse caso não há semelhança, porque, apesar dos descaminhos, Deus continua presente no universo rosiano), as obras de ambos esses autores foram igualmente assediadas pela terrível assombração do niilismo existencial. Em verdade, eles se irmanavam sob uma visão de mundo marcadamente trágica. Porque em seus universos ficcionais, a dinâmica da vida e da ação escapa à volição ou ao livre arbítrio das personagens e, ao invés da efetividade dos cálculos racionais, permanece enredada em brumas e sujeita às fúrias.

Muito mais que mera coincidência ${ }^{10}$, essa proximidade deve-se ao fato de pertencerem à mesmíssima família espiritual. "Meus irmãos [escreveu Campos de

\footnotetext{
${ }^{9}$ Palavra inicial de Grande Sertão: veredas e um dos significados de "tutaméia”, a palavra que dará título à última obra de Guimarães Rosa.

10 Eles compartilharam da mesma ambiência cultural cujas inquietações estéticas filosóficas eram razoavelmente semelhantes - o que foi devido tanto às inclinações pessoais e/ou aos rumos profissionais de cada um (lembrando que Rosa foi vice-cônsul em Hamburgo, Alemanha, durante os anos de 1938 e 1942 - o trailer do documentário sobre essa estadia na Alemanha está disponível em: <http://vimeo.com/74856362>) quanto também à impregnante presença da fenomenologia e do existencialismo no pós II Guerra e, particularmente, na cena cultural brasileira dos anos 1950 e 1960.
} 
Carvalho, em 1954] são Nietzsche, Stendhal, Lautréamont, Cesar Bórgia e Gilles de Rais. (O Marquês de Sade era meu tio por afinidade)" (CARVALHO, 1954, s/p). E, depois, num registro de parentesco muito semelhante, ele foi secundado por Guimarães Rosa, que em meados de 1964, numa entrevista, arrematou: "Unamuno poderia ter sido meu avô. Dele herdei minha fortuna: meu descontentamento" (LORENZ, 1973: 73).

Essa herança em comum ${ }^{11}$ ganhou a sua melhor expressão em Tutaméia (terceiras estórias) que foi publicada em 1967, poucos meses antes do falecimento do autor - o quê, desgraçadamente, acabou por realizar uma profecia maldita. Nessa, que seria a sua última obra, Guimarães Rosa radicalizou as experimentações de linguagem de Grande sertão: veredas, porém, assumiu uma voz cômica inusitada (RAMOS, 2009, passim). Ele reuniu quarenta contos bem curtos, cujas histórias são avulsas e, embora remetam ao mesmo universo imagético, têm frágil contiguidade narrativa podendo ser lidas aleatoriamente. A esses quarenta contos, Rosa acrescentou quatro prefácios enigmáticos e também mobilizou muitos outros recursos paratextuais (desenhos e recursos gráficos editoriais). Finalmente, enfeixou tudo isso em dois Índices diferentes — um de leitura; outro de releitura (!) - , ambos organizados por critérios ostensivamente caprichosos e igualmente precedidos por distintas epígrafes de Schopenhauer ${ }^{12}$.

Afora essa composição extravagante, soma-se o estranho significado do título Tutaméia (terceiras estórias) não quer dizer grande coisa. Ou melhor, tutaméia, segundo a definição do autor significa: "nonada, baga, ninha, inânias, ossos-de-borboleta, quiquiriqui, tuta-e-meia, meximfório, chorumela, nica, quase-nada, mea omnia" e isso quer dizer quase nada — ou, se quisermos, numa versão mais simplória: "aí tem de um tudo um pouco". (A melhor imagem que me ocorre é a da Arca de Noé: um casal daqui; um casal dali; mais outro acolá... E eis que, no fim, surge, confusa e majestosa, toda a criação... mea omnia). E quanto às "terceiras estórias", que aparecem entre parênteses como subtítulo, tal nomeação também é desconcertante. Afinal, o autor publicou os contos das Primeiras estórias em 1962 e, depois, saltou direto para Tutaméia (terceiras estórias) em 1967, sem jamais ter preenchido o intervalo da sequência numérica com as (de fato, inexistentes) segundas estórias. Anedota de abstração, o subtítulo "terceiras

\footnotetext{
${ }^{11}$ Sobre a proximidade entre Nietzsche e Unamuno, ver: SOBEJANO G. (1967) e para perspectiva diferente, cf.: Caroline GILLIS (2008).

${ }^{12}$ Epigrafe de Schopenhauer no primeiro Índice: "Daí, pois, como já se disse, exigir a primeira leitura paciência, fundada em certeza de que na segunda, muita coisa, ou tudo, se entenderá sob luz inteiramente outra". E, depois, no Índice de Releitura: "Já a construção orgânica e não emendada, do conjunto, terá feito necessário por vezes ler-se duas vezes a mesma passagem".
} 
estórias" espelha a nulidade do significado da palavra tutaméia (nonada = não + nada) e insiste em fazer gracejo com aquilo que não é, o nada, o não-ser. ${ }^{13}$ Com efeito, tal como na experiência da saudade, joga luz sobre o que é ausente e não está aqui, mas que exatamente em virtude disso, provoca efeitos e tem a força da presença.

O primeiro prefácio de Tutaméia, intitulado "Aletria e hermenêutica" — cópula que, de resto, é outra incógnita - conta e explora várias dessas anedotas de abstração. A de que eu mais gosto é esta:

- 'Em escavações, no meu país, encontraram-se fios de cobre: prova de que os primitivos habitantes conheciam já o telegrafo...'

- 'Pois no meu, em escavações, não se encontrou fio nenhum. Prova de que lá, pré-historicamente, já se usava o telegrafo sem fio.' (ROSA, 1967: 05).

Creio que essa anedota descortina alguns dos muitos significados envolvidos no enigmático título "Aletria e hermenêutica". Porque tal diálogo nos faz sorrir dos nossos próprios esforços (hermenêuticos e macarrônicos ${ }^{14}$ ) para a interpretação do mundo. Com indícios estapafúrdios ou não, seja lá como for, interpretar o mundo é sempre um gesto inventivo. Quer dizer, nossa habilidade para predicar a realidade envolve um espetacular esforço de imaginação (poética) de todos os seres e haveres do mundo. E isso, por fim, preenche a chamada "Grande Cadeia do Ser" numa escala de existência cujos degraus vão do tangível à quimera, da realidade mais radicalmente bruta e ululante à inefável e fabulosa abstração. (Refiro-me, é claro, não apenas à invenção de universos ficcionais ou artísticos, mas também à imaginação científica, matemática, gastronômica, filosófica etc... $\left.{ }^{15}\right)$.

\footnotetext{
${ }^{13}$ Essa mesma lógica de raciocínio por abstração aparece nestes outros gracejos: "Entre Abel e Caim, pulouse um irmão começado com B.. [...] Saudade é o predomínio do que não está presente, diga-se ausente. O silencio proposital dá a maior possibilidade de música" (ROSA, 1967:12).

${ }^{14}$ Hermenêutica é a arte de compreender, interpretar e traduzir o sentido "exato" do um texto. A palavra alude a Hermes, divindade grega que mantinha a comunicação entre o Olimpo e os mortais traduzindo a linguagem dos deuses para o mundo dos homens e vice-versa. Segundo Richard Palmer, ela possui três significados: dizer/anunciar; explicar; traduzir. Mas em qualquer dessas acepções trata-se de transferir uma dada mensagem estabelecendo mediação e contato entre dois mundos, planos ou domínios (isto é: entre os tempos presente e passado; de um idioma para outro; do divino para o humano etc.) Richard E. PALMER (1999).

${ }^{15}$ Além disso, vale observar que tais anedotas de abstração não são exclusivas ao mundo ficcional. Embora Herder tenha explicitamente recomendado que a "história é a ciência daquilo que é e não a ciência daquilo que poderia porventura ser", o fato é que a historiografia brasileira, por exemplo, consumiu fartas doses de energia intelectual num debate sobre um evento que jamais aconteceu: a revolução burguesa no Brasil (raciocínio típico dessas piadas de abstração...).
} 
Ademais, numa releitura de Tutaméia, convém salientar o conectivo que sustenta a cópula entre as palavras aletria e hermenêutica — afinal, aí não há excludência, pois não se trata de aletria ou hermenêutica.

Com efeito, quando aparece ao lado de hermenêutica, a palavra aletria passa a comportar um mundaréu de possibilidades interpretativas. Em seu sentido literal, aletria é um tipo de macarrão, fino e emaranhado, popularmente conhecido como "cabelinho de anjo". Além desse significado prosaico, ela guarda um sentido simbólico, já que a ironia da linguagem macarrônica é um consagrado gênero de comédia e recurso cômico. Mas afora isso, também se insinuam outros sentidos quer por razões fônicas, em virtude de familiaridade melódica (aletria / alegria — o que confirma, a um só tempo, os ânimos poéticos e a macarronice da coisa...), quer por causa do próprio "acasalamento" com a hermenêutica, isto é, com a tradição de exegese das escrituras sagradas que, desde as incursões metodológicas de Friedrich Schleiermacher, transpôs-se para as chamadas ciências do espírito, atravessou os escritos teóricos de W. Dilthey, e veio encontrar a sua melhor formulação no herdeiro de Heidegger, Hans-Georg Gadamer, que em 1960, havia acabado de publicar Verdade e método ${ }^{16}$.

Nesse registro, aletria tanto quer dizer "a-letria" (ou seja, a ausência de letramento, numa remissão aos tempos da infância (RODRIGUES, 2014), ao mundo arcaico, à cultura da oralidade etc.) quanto é Aletheia (verdade, em grego).

\begin{tabular}{c|c|c} 
Aletria & E & Hermenêutica \\
\hline Macarrão fino e emaranhado & $\leftrightarrow$ & Compreensão literal \\
\hline Macarrônico / Alegria & $\leftrightarrow$ & (In)Compreensão e comicidade \\
\hline A - letria & $\leftrightarrow$ & $\begin{array}{c}\text { Compreensão e Espanto } \\
\text { (maravilhar-se) da / na cultura iletrada - oral }\end{array}$ \\
\hline Aletheia & $\leftrightarrow$ & Compreensão e verdade (desocultar)
\end{tabular}

\footnotetext{
${ }^{16}$ Certamente, G. Rosa foi leitor de Heidegger (a quem ele não apreciava), mas não tenho comprovação de que também conhecesse a hermenêutica de Gadamer. Todavia, sabe-se que era atento ao ambiente filosófico alemão e não há razões para duvidar que também fosse leitor da última publicação de Johann Wolfgang Von Goethe Poesia e Verdade (1811) - obra que serviu de inspiração para o título do livro de Gadamer. Em suma, suspeito que "Aletria e hermenêutica" situa-se nesse debate filosófico, que resignificando a matriz aristotélica da questão da mimese, define a poesia como morada da verdade. Sobre a tradição hermenêutica, cf. Maurizio FERRARIS (2000).
} 
Se compreendida como "a-letria", significando a ausência da cultura letrada, tal palavra envolve um espesso campo semântico cujas múltiplas acepções recobririam: $1^{\circ}$ ) desde os tempos do aprendizado da linguagem, quando na primeiríssima infância (entendida no sentido etimológico, ou seja, do latim infans = sem fala), o mundo se nos apresentava sem idiomas e sob um estado de absoluto assombramento; $2^{\circ}$ ) também remete ao reino infantil, mas agora entendido como o mundo do "antes do sério", que ao invés de ser uma idade ultrapassada, consiste numa força lúdica duradoura e perene, pois constitutiva da condição humana (mesmo e também na vida adulta); $3^{\circ}$ ) passando pelo quase mágico (!) processo de letramento com sua arbitrária concatenação entre os fonemas, as palavras e as coisas; $4^{\circ}$ ) e isso também envolve uma remissão ao relato bíblico pós-Babel, quando nos primórdios da humanidade, a irrupção de variedade das falas provocou tumulto e desinteligência, mas, seguidamente, esforços hermenêuticos para a recíproca tradução (STEINER, 2005); $5^{\circ}$ ) e por fim também encerraria, numa outra chave, o mundo arcaico, marcado pelas tradições orais cujas vozes ecoam, transmitindo, as pelejas e as façanhas memoráveis da vida agreste.

Por outro lado, caso seja aproximada de aletheia, então, tangenciaria a ideia de desvelar, ou, se preferirmos um neologismo bem à moda de Guimarães Rosa, envolveria o "desesquecer". Palavra grega composta pelo prefixo de negação "a" agregado ao substantivo léthe (esquecimento), aletheia é literalmente a negação do esquecimento. Ela sugere a habilidade de avançar na contramão da correnteza do rio dos mortos, o Lethes, desfazendo os caminhos do apagamento da memória. Não se trata apenas de ser subitamente assaltado por uma lembrança; antes, envolve um lento e trabalhoso esforço, que contrariando o fluxo temporal, é capaz de resgatar do reino dos esquecidos todos os que merecem e devem ser recordados — entenda-se na acepção de acordados, despertados (CORTES, 2006). Quer dizer, trata-se de honrar os feitos heroicos, resgatá-los e narrar essa tradição e esse passado. Numa palavra, desde Heródoto, a isso se chama História!

Sendo assim, entre as idas e vindas de leituras e releituras - movimentos de ruminação que caracterizam os exercícios da exegese - aletria e hermenêutica se embaralham tornando-se cifras intercambiáveis. Em outras palavras, em Tutaméia, alegria e inteligência caminham juntas, pois o acesso à verdade não obedece à seriedade cartesiana com suas ideias claras e distintas; e, ao invés disso, compreendem e se comprazem com a barafunda do mundo. 
Há muitas razões para se comparar as últimas obras de Campos de Carvalho e de Guimarães Rosa. Publicadas na mesma circunstância histórica ( 1960), ambas foram escritos de maturidade que, por razões distintas, encerraram (no sentido de término e englobar) a produção literária dos seus respectivos autores.

Não obstante conduzam seus leitores a cenários diferentes — os dois, porém, padecem da mesma obsessão pelas viagens, ainda que no cruzar de suas fronteiras ora surjam paisagens caoticamente urbanas, ora, no mundo rosiano, a rudeza da vida rural , suas narrativas são igualmente fragmentadas e, tal como na poesia, esgarçaram os limites da linguagem, explorando apelos sonoros que se embaralham numa cadência (dis)rítmica e cacofônica. Seus respectivos universos ficcionais, portanto, se apresentam em desalinho, num estado de permanente desordem. E isso expressa um rompimento com a ambição mimética de re-apresentar o mundo numa unidade narrativa razoável, coerente e progressivamente concatenada. Em verdade, suas obras ironizam tal ambição e têm fortes acentos lúdico-humorísticos — apesar de possuírem dicções cômicas notavelmente distintas: em Campos de Carvalho a gargalhada é corrosiva, exalando um sopro debochado e anárquico contra a idiotia da vida rotineira; ao passo que, em Tutaméia, o humor é silente, um sorriso pálido que, ao flertar com a alegria, encontra a beleza e os gracejos, mas também se surpreende com a gratuidade da existência — sem esquecer, é claro, da gratuidade das bênçãos divinas; eis as fúrias, novamente... (ARAÚJO, 2001).

O púcaro búlgaro e Tutaméia (terceiras estórias) compartilham da mesma visão lúdica e ante-racional da condição humana. Apesar de terem graus diferentes de humor e gaiatice, ambas essas obras romperam com o realismo artístico e igualmente difundiram um regime de prazeres (estéticos) decididamente moderno. As peças de Nelson Rodrigues já haviam experimentado esse caminho marcado pela indeterminação e ambiguidade da graça - e, penso eu, foi o dramaturgo quem realmente enfrentou e “domesticou” a crítica e o público. De qualquer forma, todas essas obras se apresentam como simples jogos de passatempo. Porque, embora não saibam explicar os sentidos da existência, "só" querem impregnar e ocupar o tempo da vida com (a gratuidade da) a arte.

\section{Fontes}

CARVALHO, Campos de. (2002 [1964]) O púcaro búlgaro.Obra reunida. RJ: José Olympio Editora, $3^{\text {a }}$ edição. 
(2001) [1954]. “Ego. Alter ego" Tribo. OLIVEIRA, Nelson. Campos de Carvalho, o último satanista. Agulha, Revista de Cultura. Fortaleza - São Paulo, n. 9, fevereiro, 2001. Disponível em <http://www.jornaldepoesia.jor.br/ag9carvalho.htm>. Acesso em: 27 set. 2014.

RODRIGUES, Nelson. A Falecida (2010 [1953]). 4 ed. Rio de Janeiro: Nova Fronteira. ROSA, Guimarães (1967). Tutaméia (terceiras estórias). Rio de Janeiro: José Olympio Editora.

\section{Referências Bibliográficas}

ARAÚJO, Heloisa V. (2001). As três graças. São Paulo: Mandarim.

ARAÚJO, Inácio (s/d). A falecida. In Portal Brasileiro de Cinema. Disponível em: $<$ http://www.portalbrasileirodecinema.com.br/nelson/obra\%20adaptada/cinema/0 2_01_05.php>. Acesso: 02 jul. 2014.

BATELlA, Juva (2004). Quem tem medo de Campos de Carvalho? Rio de Janeiro: 7Letras.

CÔRTES, Norma (2006). Descaminhos do método. Notas sobre história e tradição em Hans-Georg Gadamer. Revista Varia História. vol. 22, n. 36, jul./dez., pp. 274-290.

ENCICLOPÉDIA ITAÚ CULTURAL (s/d). Verbete A Falecida. Disponível em: $<$ http://www.itaucultural.org.br/aplicexternas/enciclopedia_teatro/index.cfm?fuse action=espetaculos_biografia\&cd_verbete=464>. Acesso em: 02 jul. 2014.

FERRARIS, Maurizio (2000) .Historia de la hermenéutica. Madrid: Akal.

GILLIS, Caroline (2008). Unamuno y Nietzsche, una oposición insuperable. Cuadernos de la Cátedra Miguel de Unamuno, n. 46, pp. 2-2008.

HOUAISS, Antonio (2002). Dicionário Eletrônico Houaiss da Língua Portuguesa. Rio de Janeiro: Objetiva.

LORENZ, Gunter W. (1973). Diálogo com a América Latina. São Paulo: E.P.U.

MAGALDI, Sábato (2004). Teatro da obsessão: Nelson Rodrigues. São Paulo: Global.

MARQUES, E Fernando. (2012). A comicidade da desilusão. Brasília: Editora UNB, 2012.

MOISÉS, Carlos F (2002). Introdução. CARVALHO, Campos de. Obra reunida. Rio de Janeiro: José Olympio Editora.

OLINTO, Antonio (1966). A verdade da ficção. Rio de Janeiro: Editora Brasileira de Artes Gráficas.

PALMER, Richard E. (1999). Hermenêutica. Lisboa: Edições 70.

RAMOS, Jacqueline (2009). Risada e meia. Comicidade em Tutaméia. São Paulo: Annablume.

RODRIGUES, Camila (2014). Escrevendo a lápis de cor: infância e história na escritura de Guimarães Rosa. Tese (Doutorado em História Social). Universidade de São Paulo, São Paulo.

ROUANET, Sérgio .P. (2007) Riso e melancolia. São Paulo: Companhia das Letras.

Site Nelson RODRIGUES (s/d). Obras adaptadas para o cinema. Disponível em <http://www.nelsonrodrigues.com.br/site/obras_cinema.php>. Acesso em: 03 jul. 2014.

Site Templo cultural Delfos (s/d). “João Guimarães Rosa: Fortuna crítica VI: Tutaméia (terceiras estórias)”. Disponível em: <http://www.elfikurten.com.br/2011/01/guimaraes-rosa-o-medico-das-almaso.html>. Acesso em: 15 ago. 2014. 
SOBEJANO G. (1967). Nietzsche en España: Madrid, Gredos.

STEINER, George (2005). Depois de Babel. Questões de linguagem e tradução. Curitiba: Editora da UFPR.

VOGT, Carlos e WALDMAN, B. (1985). Nelson Rodrigues. Flor de obsessão. São Paulo: Brasiliense.

Artigo recebido em 20 de agosto de 2016.

Aprovado em 30 de setembro de 2016.

DOI: 10.12957/intellectus.2015.26664 